(Doriden), methyprylone (Noludar), ethchlorvynol (Arvynol), and meprobamate (Miltown, Equanil) (Brit. med. F., 1964 ; Wood and Flippin, 1965). The clinical features described in these studies correspond very closely with those found in our patient.

Methaqualone has been shown to be a potent hypnotic (Parsons and Thomson, 1961 ; Duchastel, 1962). It is marketed in the United Kingdom as Melsedin, and in combination with diphenhydramine as Mandrax. It is sold in the U.S.A. as Quaalude. Melsedin was described as a non-barbiturate hypnotic that "produces natural sleep" and to which neither tolerance nor addiction had been attributed. The makers have told us that they now know of four cases of addiction, in addition to the one reported here, three of the patients concerned having a history of addiction also to barbiturates or alcohol (J. W. Buckler, personal communication, 1966).

Mandrax is claimed to have an action that is " quite different from that of the barbiturates and almost all other hypnotics." No addiction had been reported to the makers, who pointed out (February 1966) that their product had been generally available for only four months (A. L. Macnair, personal communication, 1966).

Though recent neurophysiological methods of investigation of the action of drugs on sleep (Oswald and Thacore, 1963 ; Oswald and Priest, 1965) may eventually clarify the relevance of withdrawal syndromes, at present the clinical picture of

\section{Thrombocytopenic Purpura in Patient with Autoimmune Haemolytic Anaemia, Successfully Treated with Mercaptopurine}

\author{
Brit. med. F., 1967, 3, 93-94
}

Before the introduction of corticosteroids in 1949 splenectomy and blood transfusions were the only well-established treatments for autoimmune haemolytic anaemia (Dacie, 1954; Schwartz and Dameshek, 1962). Corticosteroids rapidly became the treatment of choice, splenectomy being reserved for refractory cases. Dameshek and Schwartz (1960) reported the use of purine antagonists in the management of autoimmune haemolytic anaemia, and this has now been accepted as an additional treatment. It has been suggested that primary thrombocytopenic purpura and acquired haemolytic anaemia might have a common aetiology (Evans et al., 1951), since thrombocytopenia may be a feature of autoimmune haemolytic anaemia, and in a proportion of cases platelet antibodies can be demonstrated.

In the following case a relapse of thrombocytopenic purpura occurred in a patient with autoimmune haemolytic anaemia who had previously been treated by corticosteroids and splenectomy. High doses of corticotrophin temporarily controlled the thrombocytopenia, which later was successfully treated with mercaptopurine.

\section{CASE Report}

A 17-year-old youth was admitted to hospital in January 1962 with a three-months history of increasing weakness and lassitude. Immediately before admission he developed high fever, became jaundiced, and stanted passing dark urine. There was no relevant past or family history, and no history of blood transfusion or exposure to drugs or poisons.

Physical examination showed a febrile, pale, jaundiced youth with slight hepatosplenomegaly. Investigations showed haemoglobin 3.5 g. $/ 100 \mathrm{ml}$.; reticulocytes $31 \%$; W.B.C. $22,800 / \mathrm{cu}$. mm., normal differential ; platelets $48,000 / \mathrm{cu}$. mm. ; serum bilirubin $5.2 \mathrm{mg}$./ delirium tremens is one means of categorizing the pharmacological action of psychotropic drugs. Apart from the remarkable experiments of Isbell and his colleagues it seems that at present we must rely on those patients who abuse their drugs to assist us in this classification.

We are grateful to Professor J. A. Strong for permission to report this case, and to the manufacturers for the information mentioned above.

ROBIN B. LOCKHART EWART, M.B., CH.B., B.SC., Department of Medicine, Western General Hospital Edinburgh 4.

RoBIN G. PRIEST, M.B., B.S., M.R.C.P.ED., D.P.M. Department of Psychiatry, University of Edinburgh

\section{REFERENCBS}

Brit. med. f., 1964, 2, 1412.

Duchastel, Y. (1962). Canad. med. Ass. 7., 86, 586.

Isbell, H., Altschul, S., Kornetsky, C. H., Eisenman, A. J., Flanar H. G., and Fraser, H. F. (1950). Arch. Neurol. Psychiat. (Chic.), 64, 1 .

Fraser, H. F., Wikler, A., Belleville, R. E., and Eisenman, A. J. (1955).' Quart.' Y. Stud. Alcohol, 16, 1.

Madden, J. S. (1966). Brit. med. Y., 1, 676.

Martin, G. J. (1966). Ibid., 2, 114 .

Oswald, I., and Priest, R. G. (1965). Ibid., 2, 1093

Oswald, I., and Priest, R. G. (1965) ibid., 2, 127.

Parsons, T. W., and Thomson, T. J. (1961). Ibid., 1, 171

Wood, H. P., and Flippin, H. F. (1965). Amer. F. Psychiat., 121, 1127.

$100 \mathrm{ml}$. (1.5 mg. direct). A direct Coombs test was positive. Autoimmune haemolytic anaemia was diagnosed and treatment with prednisone was started, and within four weeks the peripheral blood picture had returned to normal. On a maintenance dose of prednisone $10 \mathrm{mg}$./day he remained well, with a normal haemoglobin and platelet count, until early in 1964, when he developed a diffuse petechial rash. Platelets numbered $24,000 / \mathrm{cu}$. mm., and after increased doses of prednisone $(20 \mathrm{mg}$./day) had failed to control the thrombocytopenia splenectomy was performed in March 1964. The platelet count did not rise greatly after operation, and prednisone $10 \mathrm{mg} . /$ day was restarted with considerable improvement. On this dose of prednisone for the next year the platelet count remained between 100,000 and $200,000 / \mathrm{cu}$. $\mathrm{mm}$.

In July 1965 he was readmitted to hospital with a recurrence of purpura and a platelet count of $20,000 / \mathrm{cu}$. mm. A corticotrophin infusion produced a satisfactory rise in platelet count to 200,000 / cu. $\mathrm{mm}$., and this was maintained as long as the dosage of corticotrophin was not dropped below 80 i.u./day. During a two-months course of corticotrophin administration the patient gained $35 \mathrm{lb}$. $(15.9 \mathrm{~kg}$.) and developed many features of Cushing's syndrome.

In October he was admitted to hospital for a trial of mercaptopurine. On examination he presented the appearance of Cushing's syndrome, with moonface, buffalo hump, high colour, and abdominal striae. Blood pressure was 160/120. The initial peripheral blood picture was: $\mathrm{Hb} 14.9 \mathrm{~g} . / 100 \mathrm{ml}$. ; W.B.C. $11,800 / \mathrm{cu}$. mm., normal differential ; platelet count $230,000 / \mathrm{cu}$. mm.; E.S.R. $3 \mathrm{~mm}$. in first hour ; blood was also examined for lupus erythematosus cells with negative results. A direct Coombs test was positive in a dilution of $1 / 16$, but serological study failed to reveal platelet or leucocyte agglutinins or incomplete platelet antibodies, and the red cell antibody showed no specificity. Apart from a serum potassium of 2.7 $\mathrm{mEq} / \mathrm{l}$. on admission, later corrected by oral potassium supplements, other electrolytes were all normal. The urine contained a trace of sugar. Blood-volume studies showed a normal red cell mass and plasma volume, and $\mathrm{T} \frac{1}{2}{ }^{51} \mathrm{Cr}$ red cell survival was 27.5 days.

At the time of admission on 4 October he was receiving corticotrophin 40 i.u. b.d. On the following day treatment with mercaptopurine $150 \mathrm{mg}$. o.d. was started, and during the next three weeks the corticotrophin was gradually reduced, finally being stopped on 24 October. Meanwhile the patient noticed transient symptoms of dizziness and lassitude. At the same time the urine became free of sugar, the blood pressure settled to normal, and he lost $14 \mathrm{lb}$. (6.4 kg.) in weight. During a 23-days course of treatment with 
mercaptopurine the platelet count ranged between 40,000 and $180,000 / \mathrm{cu}$. mm., and the white cell count fell steadily from 21,000 coon after admission to 3,200 (see Chart).

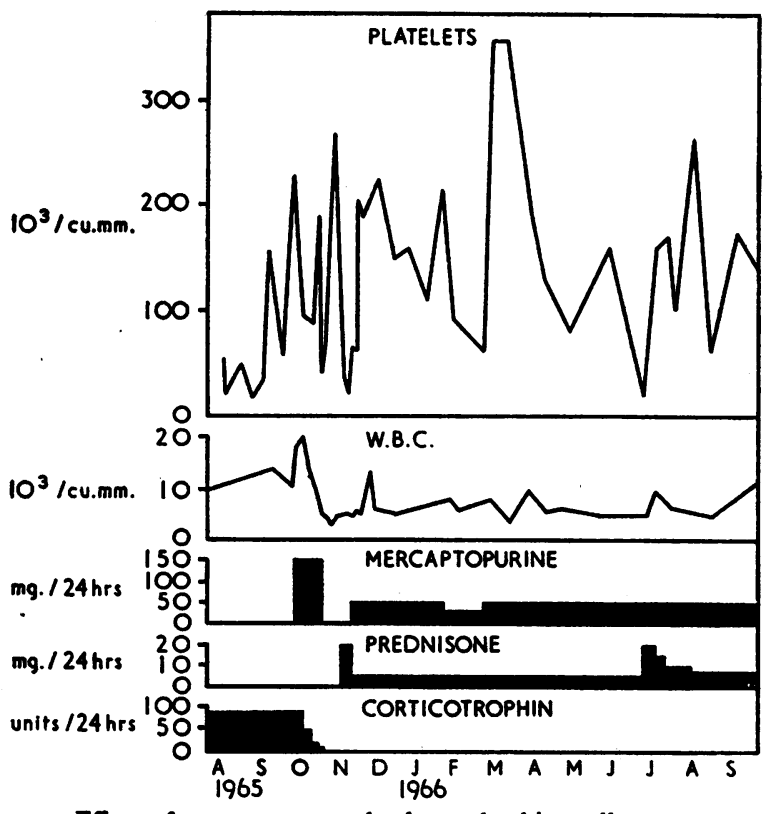

Effect of treatment on platelet and white cell count.

The patient was discharged without purpura on 8 November, with a platelet count of $270,000 / \mathrm{cu}$. $\mathrm{mm}$. He was not receiving treatment. Five days later, having developed diffuse purpura, he was readmitted to hospital with a platelet count of $33,000 / \mathrm{cu}$. mm. Prednisone $20 \mathrm{mg}$./day was started immediately, but when, on 19 November, a platelet count was only $62,000 / \mathrm{cu}$. mm. mercaptopurine was reintroduced at a dosage of $50 \mathrm{mg}$./day and the prednisone cut to $5 \mathrm{mg} . /$ day. Three days later a platelet count was $204,000 / \mathrm{cu}$. 'mm., and during the next two and a half months on this drug regimen it remained between 100,000 and $200,000 / \mathrm{cu}$. mm.

On 1 February 1966 the dosage of mercaptopurine was halved to $25 \mathrm{mg}$./day, and this was followed on 1 March by a recurrence of purpura (platelets $58,000 / \mathrm{cu}$. mm.). Mercaptopurine was increased to $50 \mathrm{mg} . /$ day, and a week later there was no new purpura and the platelets were $360,000 / \mathrm{cu}$. $\mathrm{mm}$. On this regimen of treatment the patient remained well until 3 July, when he developed purpura. When seen at the hospital two days later a platelet count was 18,000 / cu. mm., W.B.C. 5,600/cu. mm., and $\mathrm{Hb} 16 \mathrm{~g} .1100 \mathrm{ml}$. No cause for the relapse of purpura was established, and the dosage of prednisone was increased to $20 \mathrm{mg}$./day. Eight days later there was no sign of purpura, a platelet count was $186,000 / \mathrm{cu}$. mm. and W.B.C. $10,800 / \mathrm{cu}$. mm. Since then the dosage of prednisone has been gradually reduced, and at the time of writing the patient was very well, had no leucopenia, and was able to work as a clerk. On several occasions during the last few months when the prednisone was omitted for a few days he has complained of feeling unwell, but this always cleared as soon as the prednisone was restarted.

\section{Discussion}

The occurrence of autoimmune haemolytic anaemia and thrombocytopenia has been recognized for many years (Evans and Duane, 1949). The frequency of their association is not known, but in a series of 83 cases of autoimmune haemolytic anaemia (warm antibody) reported by Dausset and Colombani (1959) $13.2 \%$ had a concurrent thrombocytopenia.

In addition to corticosteroids antimetabolite drugs have recently been reputed to be beneficial in the treatment of haemolytic anaemia and thrombocytopenia. Richmond et al. (1963) reported a case in which a fulminating haemolytic anaemia and thrombocytopenia developed some time after splenectomy for idiopathic thrombocytopenia. Large doses of corticosteroids were ineffective and thymic irradiation produced only transitory improvement. The thrombocytopenia and anaemia were finally controlled by Imuran (azathioprine) and actinomycin C. Matthews (1965) reported the successful use of Imuran in the treatment of a patient with idiopathic autoimmune haemolytic anaemia and idiopathic thrombocytopenia associated with diffuse hypergammaglobulinaemia, amyloidosis, hypoalbuminaemia, and plasmacytosis. Bouroncle and Doan (1966) reported seven cases of refractory idiopathic thrombocytopenic purpura treated with Imuran. In four of their cases several months' treatment with prednisone and Imuran led to a remission of thrombocytopenia, which was sustained when the drugs were stopped. In two of their cases a definite improvement in platelet count accompanied continuous treatment with the same drugs.

In this case thrombocytopenia developed two years after the appearance of an autoimmune haemolytic anaemia, which was then in remission. Prednisone successfully controlled the thrombocytopenia after splenectomy had failed. A further two years later thrombocytopenia relapsed. Large doses of corticotrophin produced a temporary remission, but in view of the rapid development of signs of corticosteroid overdosage alternative treatment was essential. A trial of mercaptopurine proved successful, and the patient remained well on a maintenance dosage of mercaptopurine and prednisone. This case supports the finding of Bouroncle and Doan (1966) that corticosteroids seem to have an additive effect with antimetabolites in obtaining remission of thrombocytopenia.

My thanks are due to Professor T. A. J. Prankerd and Dr. R. N. Tattersall for permission to publish this case; and to Dr. A. J. Bowdler, who performed the plasma volume and red cell survival studies.

\section{H. N. TATTERSAlL, M.A., M.B., B.CHIR.}

\section{RBPBRENCBS}

Bouroncle, B. A., and Doan, C. A. (1966). New Engl. F. Med., 275, 630. Dacie, J. V. (1954). The Haemolytic Anaemias. London.

Dameshek, W.. and Schwartz, R. (1960). Trans. Ass. Amer. Phycns, 13, 113.

Dausset, J., and Colombani, J. (1959). Blood, 14, 1280.

Evans, R. S., and Duane, R. T. (1949). Ibid., 4, 1196.

- Takahashi, K., Duane, R. T., Payne, R., and Liu, C.-K. (1951). Arch. intern. Med., 87, 48.

Matthews, R. J. (1965). Amer. 7. Med., 39, 972.

Richmond, J., Woodruff, M. F. A., Cumming, R. A., and Donald, K. W. (1963). Lancet, 2, 125 .

Schwartz, R., and Dameshek, W. (1962). Blood, 19, 483. 